Dialectologia 28 (2022), 225-241.

ISSN: 2013-2247

Received 29 January 2020.

Accepted 18 April 2020.

\title{
PRONUNCIATION AND LINGUISTIC BIAS IN INTERVIEWING ARABIC INSTRUCTORS
}

\author{
Wael ZURAIQ ${ }^{1}$, Mohammad Al OMARI ${ }^{2} \&$ Sabri Al SHBOUL ${ }^{3 *}$ \\ ${ }^{1}$ Hashemite University / ${ }^{2}$ Hashemite University / ${ }^{3}$ Hashemite University \\ zuraiq@hu.edu.jo / maalomari@hu.edu.jo / sabri@hu.edu.jo
}

\begin{abstract}
The present qualitative study reports on a sample of six Arabic instructors (out of 30) who were asked to modify/correct their pronunciation of Arabic as it was considered "unsuitable" by members of the recruitment committee. Almost half the instructors believed that the corrections involved linguistic bias. The others did not take issue and welcomed such direction since they believed that modification may improve the learning-teaching process by using a common educated accent that is suitable for all. The study described the linguistic truth for Arabic instructors in terms of regional pronunciation. It could be applied to both first- and second-language settings where instructors are required to accept that their local pronunciation is non-professional and is unsuitable for teaching. This qualitative study is undertaken for the betterment of our perception toward language diverse identities. The findings are discussed within Social Identity Theory.
\end{abstract}

Keywords: sociophonetics, Arabic, language of instruction, pronunciation bias, speaker identity

\section{PRONÚNCIA I BIAIX LINGÜÍSTIC EN LES ENTREVISTES A INSTRUCTORS ÀRABS}

\section{Resum}

Aquest estudi qualitatiu se centra en una mostra de sis professors d'àrab (de 30) a qui es va demanar que modifiquessin/corregissin la seva pronúncia de l'àrab, ja que els membres del comitè de contractació la consideraven "inadequada". Gairebé la meitat dels instructors creien que les correccions tenien un biaix lingüístic. Els altres no s'hi van oposar i van estar d'acord amb aquesta instrucció, ja que creien que la modificació podia millorar el procés d'aprenentatge-ensenyament mitjançant un accent comú adequat per a tothom. L'estudi descriu l'evidència lingüística dels professors d'àrab en termes de pronunciació regional. Es podria aplicar tant a entorns de primera llengua com de segona on els professors han d'acceptar que la pronunciació local no és professional i no és adequada per a l'ensenyament. Aquest estudi qualitatiu es va dur a terme per millorar la percepció envers les identitats diverses del llenguatge. Els resultats s'analitzen en el marc de la Teoria de la identitat social.

\footnotetext{
* The Hashemite University. P.O. Box 330127, Zarqa 13133, Jordan.
} 
Paraules clau: sociofonètica, àrab, Ilengua d'instrucció, pronúncia esbiaixada, identitat del parlant

\section{PRONUNCIACIÓN Y SESGO LINGÜÍSTICO EN LAS ENTREVISTAS A INSTRUCTORES ÁRABES Resumen}

Este estudio cualitativo se centra en una muestra de seis profesores de árabe (de 30) a quien se pidió que modificaran / corrigieran su pronunciación del árabe, ya que los miembros del comité de contratación la consideraban "inadecuada". Casi la mitad de los profesores creían que las correcciones tenían un sesgo lingüístico. Los otros no se opusieron y estuvieron de acuerdo con esa instrucción, ya que creían que la modificación podía mejorar el proceso de aprendizaje-enseñanza mediante el uso de un acento común adecuado para todos. El estudio describió la evidencia lingüística de los profesores de árabe en términos de pronunciación regional. Podría aplicarse tanto a entornos de primera como de segunda lengua en los cuales los profesores deben aceptar que su pronunciación local no es profesional y no es adecuada para la enseñanza. Este estudio cualitativo se llevó a cabo para mejorar la percepción hacia las identidades diversas del lenguaje. Los hallazgos se analizan en el marco de la Teoría de la identidad social.

Palabras clave: sociofonética, árabe, lengua de instrucción, pronunciación sesgada, identidad del hablante

\section{Introduction and problem}

Giles \& Johnson $(1981,1987)$ established ethnolinguistic identity theory by concentrating on language as a major sign of group attachment and identity. They theorize that members of a group match theirs to other out-groups so that they feel unique, and that uniqueness empowers them to accomplish an advantageous group identity. But if the comparison is undesirable, individuals opt to assimilate into another more fortunate group. If a language or a dialect or an accent is an important indicator of a group membership, speakers may adapt to new code; and this can cause unjust bilingualism or dialect/accent loss. Teachers' linguistic identity has become a concern of linguistic research (Gutierrez \& Orellana 2006; Godley \& Escher 2012; Haddix 2010, 2012; Reaser 2016; Baratta 2018). Deprez-Sims \& Morris (2010) declare that pronunciation is as noticeable as ethnicity and skin colour. Lippi-Green (1997) discusses how heterogeneous workplace pronunciation has obvious consequences; for instance, an Indian woman is considered unfit for a librarian's position because of her "heavy accent" (Liberman 2010). 
Instructors who exhibit a regional pronunciation of Arabic may be considered unacceptable in the teaching-learning environment. For instance, countryside pronunciation (rural Arabic) and Bedouin pronunciation do not meet classroom standards. There can be a difference between regional pronunciation and that expected in academia, even if the instructor is an expert in his own field of study (Baratta 2017). This phenomenon intimidates both native and non-native Arabic instructors. In the past, teachers were categorized as skilled workers who were required simply to use the best teaching approach for students to learn successfully. However, the teacher's identity is itself significant (Nunan 1988; Woods 1996). Such positive change in the philosophy of teaching focuses on identity as a key element in deciding how language teaching should be thought of, since teachers are not neutral contributors in the teaching space (Norton 2000). Accordingly, the teacher's identity has become a key element in the socio-cultural scene of the teaching space. Who teachers are vis-à-vis their identity is complex (Casanave \& Schecter 1997). Identity is a changeable tool and not context-free (Duff \& Uchida 1997; Norton Peirce 1995; Sarup 1996). Teachers find themselves in a struggle between "imposed identity" and "claimed identity" (Buzzelli \& Johnston 2002). Today, identity is shaped, sustained and negotiated via language and discourse. Varghese et al. (2005: 35) defined three major themes of language teacher identity:

1. Identity as multiple, shifting, and in conflict;

2. Identity as crucially related to social, cultural, and political context;

3. Identity being constructed, maintained, and negotiated primarily through discourse.

Tajfel \& Turner's (1986) Social Identity Theory refers to the notion that one's sense of 'who he is' depends on the group which he belongs to (e.g., family, tribe, social class, football team). This group forms a significant source of pride and selfesteem. Three mental processes were proposed which to evaluate others as "us" or "them: social categorization, social identification, and social comparison. With the existence of more than one group, the tendency towards comparison between the groups emerges as a result of the competing identities (Tajfel \& Turner 1979). Tajfel 
(1974, 1981) provided one of the best prominent philosophies of social identity; he assumed that identity is dependent on group association. Yet, people may opt to alter their group association if it does not satisfactorily fulfill their positive identity. Gumperz (1970) and Heller (1988) believe that group membership is established and maintained via linguistic codes. They examined code switching between languages and between varieties of the same language. They found that code switching does indicate several group memberships and identities.

The fact that Arabic varies within each country and across Arab countries results in accent labelling with negative and/or positive associations. The authors of the study noticed that employers, employees and students associate certain accents with different characteristics. The following list shows some frequent associations, both positive and negative, for a number of selected dialects of Arabic as observed by authors:

$\begin{array}{llll} & & \text { Positive } & \text { Negative } \\ \text { 1. } & \text { Lebanese } & \text { sexy } & - \\ \text { 2. } & \text { Syrian } & \text { euphemistic } & - \\ \text { 3. } & \text { Jordanian } & - & \text { diseuphemistic } \\ \text { 4. } & \text { Gulf } & \text { poetic } & - \\ \text { 5. } & \text { Yemeni } & - & \text { incoherent } \\ \text { 6. } & \text { Iraqi } & - & \text { rough } \\ \text { 7. } & \text { Egyptian } & \text { musical } & - \\ \text { 8. } & \text { Sudanese } & - & \text { funny } \\ \text { 9. } & \text { Moroccan } & - & \text { difficult to understand } \\ \text { 10. } & \text { Palestinian } & - & \text { complicated }\end{array}$

Such associations may generate admiration or disapproval in the context of education. Pronunciation deemed "educationally unsuitable" may have serious implications for Arabic instructors who have regional accents. In Jordanian context, there are three main accents: Urban, Rural and Bedouin. Urban dialect is the dominant accent in the capital, and the accent favoured by educated and stylish people in Amman and other cities like Irbid and Zarqa. Rural dialect is dominant in the northern 
(Irbid, Rumtha, Ajlun, and Jerash) representing the accent of the local inhabitants of the rural areas. Bedouin dialect(s) is the widely admired accent of "honorable" Bedouin/Nomadic tribes (e.g., Bani Hassan Bedouin, Bani Saxar, Shammari, Anazi). For details of the linguistic situation of Jordanian dialects read Sakarna (2005). Table 1 shows the linguistic diversity for the four three main accents:

\begin{tabular}{|c|c|c|c|}
\hline Standard Sound & Urban & Rural & Bedouin \\
\hline$\theta$ & $\mathrm{t}$ & $\theta$ & $\theta$ \\
\hline d3 & 3 & d3 & d3 \\
\hline ठ & $\mathrm{d}$ and $\mathrm{z}$ & б & б \\
\hline$q$ & $?$ & g & $\mathrm{g}$ \\
\hline$k$ & $\mathrm{k}$ & $\mathrm{t} \int$ & t $\int$ \\
\hline Emphatic d $^{\varsigma}$ & $d$ & ठ and $\partial^{\varsigma}$ & $\delta^{\varsigma}$ \\
\hline Emphatic す & $z^{\varsigma}$ & $\delta^{\varsigma}$ & $\delta^{\varsigma}$ \\
\hline Emphatic $t^{\varsigma}$ & $\mathrm{t}$ & $t^{\varsigma}$ & $t^{\varsigma}$ \\
\hline$a_{1}$ & $\mathrm{e}_{\mathrm{l}}$ & $\mathrm{e}_{\mathrm{l}}$ & $e_{1}$ and $\mathrm{i}:$ \\
\hline$a v$ & әи & әu & әи \\
\hline$æ$ & $æ$ & $æ$ and $a^{\varsigma}$ & a: \\
\hline
\end{tabular}

Table.1. Main segmental difference between the three Jordanian accents

Since there are several native regional groups (Hammarström et al. 2017) in Jordan, there is much linguistic diversity. Besides Standard Arabic, instructors with the three different accents tend to assert their group identity on campus since pride in group identity is appealing. Many instructors in Jordan tend to stress their connection to the group they belong to by overrating its habits, traditions and accents. Moreover, Jordan has millions of refugees: Palestinian, Iraqi, Libyan, Syrian and Yemeni.

It is educationally rational to approve diverse pronunciations since Arabic is pronounced differently in more than 20 countries across the Middle East and North Africa. In all these countries we can also still find sub-accents. Nevertheless, in almost all Arab countries instruction tends to be linked to Standard Arabic. A fundamental question is how instructors are perceived, vis-à-vis their regional or local pronunciations; a pronunciation perceived as unsuitable may have negative 
implications, whereas standard pronunciation is often viewed as more correct in many languages (Kelch \& Santana-Williamson 2002; Beinhoff 2016).

Concerning the selection process for employment, even good instructors are being "educated" in how to educate (Baratta 2018). However, there are no reports, to our best knowledge, examining the fundamental question of bias against Arabic instructors. If instructors accept as true that their pronunciation is a problem, even they are skilled teachers, and then the present study may strengthen our understanding of this pivotal issue which is relevant to our future education policies. We hypothesize that although there is an emphasis on linguistic equality, many instructors are persuaded to understand that their regional pronunciation is an impediment. Such bias is more likely to annoy them during interviews. This study aims at making educational institutions more aware of the bias against certain instructors with unsuitable pronunciation practiced by some job interviewers.

\section{Data collection}

Since the current study focuses on human behavior and the societal and educational contexts within which it occurs (Salkind 2006), and since we are not yet investigating the cause and effects of linguistic bias; a qualitative method is used.

In qualitative research, methods of data collection include observation, textual or visual analysis and interviews, with interviews and focus groups the most popular. Semi-structured interviews are used because of their flexibility in allowing the interviewees to elaborate on facts that are essential to them but may not originally have been thought of as relevant by the research team. Interviews are therefore productive of a wide range of information.

First, instructors who had recently been interviewed by the recruitment committee of the Learning Centre were invited to participate in the study voluntarily. They were informed about the research (purpose, length of interview, offer for withdrawal if needed, potential benefits and risks) and were assured about the confidentiality and anonymity of their responses, encouraging their trust in the 
research process. In our interviews, questions were open-ended and easy to understand. Most interviews took place in a comfortable venue, free from interruption. We adopted an emotionally neutral body language. We started with straightforward questions before moving on to the main issue. Participants were given the option of sending their replies and feedback by email. Interviews lasted 15 to 25 minutes. We took field notes during and immediately after each interview. The notes were subsequently translated into English. Thirty participants (15 males and 15 females) were interviewed. The age of participants ranged from 25 to 35 . Twenty participants had MA and ten participants had PhD at the time of the interview.

\section{Questions about the recruitment interview}

1. How was your interview?

2. What made your interview interesting or uninteresting?

3. How did you respond when the interviewers commented on your presentation?

4. Do you feel that there is anything else to discuss about your presentation?

\section{Remarks from instructors}

Below is a careful selection of remarks provided by six Arabic instructors who were told by the recruitment committee to correct their regional pronunciation. Three of them felt that directives indicated a biased approach, but the other three had no issue with it. The following comments illustrate both sides.

2.1 Remarks provided by Arabic instructors who were told to correct their pronunciation and who felt that correction was an inappropriate approach.

\section{Instructor $A$}

Instructor A recently completed his $\mathrm{PhD}$ in Arabic language and literature. He has a Bedouin accent, from the northeastern part of Jordanian Badiya. Before he was 
appointed as an instructor of Arabic language he was invited to give a presentation at the Arabic Language Centre in front of the recruitment committee. He reported:

After the presentation, the members of the recruitment committee interviewing me believed that the presentation was weak. They said that the job is about teaching Standard Arabic, but I was pronouncing it inappropriately myself! They alleged that most experts in Standard Arabic would not offer me even temporary employment if I wasn't fluent in Standard Arabic, for the reason that good students from urban regions would be irritated by my inappropriate vowels, and might drop out of the course! I felt so discriminated against. One interviewer argued that I should "conceal" my local pronunciation. I agreed with them to hide my unsuitable pronunciation and told them I would avoid using inappropriate vowels. Now I feel appalled because of this biased interview and angry with myself for bargaining.

Initially, the definition of Standard Arabic is itself problematic. Our notions about standardization come from the prescriptive purists who define it as the Classical Arabic of the earliest poetry. Most grammarians would only accept the grammar of poetry dating back 1500 years. Classical Arabic is also recognized as Quranic Arabic (even though the term is not exclusive), Paradoxically, the language and grammar of both ancient Arabic poetry and Quranic Arabic came from the language used by several different tribes with a variety of accents. Current accents are also considered as a continuation of the old Arabic spoken in the Arabian Peninsula. The peninsula consists of the United Arab Emirates, Yemen, Qatar, Bahrain, Kuwait, Saudi Arabia and Oman. Previously, the Arabian Peninsula was divided into four separate regions with distinct accents: Najd (Al-Yamama), Hejaz (Tihamah), Southern Arabia (Hadhramaut) and Eastern Arabia. Southern Arabia consists of Yemen and some parts of Saudi Arabia (Najran, Jizan, Asir) and Oman (Dhofar). Another definition of Standard Arabic is as the language used for writing and in most formal speech all over the Arab world. If it is the language of writing with its sophisticated style, then this may not automatically make it a flexible mode for spoken communication. Teaching may require a more reciprocally 
flexible style for both the instructor and the pupil. If the instructors themselves are not comfortable with the way they speak in class, this may result in a degree of frustration and consequently low-quality teaching and poor interaction with students. For details, read (Ingham 1982; Palva 1991, 2006; and Watson 2011).

\section{Instructor B}

Instructor B has an MA in Arabic Linguistics. Her native accent is rural, dominant in the north of Jordan. She is one of several instructors who were directed to modify their rural accent. She talked to us directly about her interview with members of the recruitment committee concerning her exaggerated emphatic sounds. Exaggerated emphatic sounds (with secondary articulations) are very noticeable in rural pronunciation since emphasis also spreads to other non-emphatic sounds, both consonants and vowels. She felt that teamwork in the workplace would be difficult with supervisors thinking that her pronunciation was "extravagant" She said that:

I am totally aware of my different emphatic sounds and the way they naturally spread to other non-emphatic adjacent sounds, but I think that this is my accent and I should not be ashamed of my natural way of speaking. On the contrary, I am proud of my accent which has been heard over the country for hundreds of years. I felt that the committee wanted me not to fix my pronunciation but rather to fix my identity. Moreover, although I speak in a different way from most instructors, I have heard many university students speak the way I speak.

She felt that her way of speaking is a very natural one. She argued that her pronunciation is part of her identity and part of her pride in her group and region; her people have lived in Jordan for centuries using this rural accent across all the villages. Since this accent is used by many university students, it must not be disrespected. Garrett (2010) argues that the "toughness" of regional or local accents is found "attractive" by many audiences. 


\section{Instructor $C$}

Instructor $\mathrm{C}$ has a PhD in Modern Arabic Literature. Her regional accent is Urban. Urban may also be referred to as Ammani, since it is used in the capital city by stylish and rich people whose grandparents migrated from cities like Haifa, Java and Jerusalem. She also said that she was directed to modify her Urban pronunciation of many consonants. Six Urban consonants differ from the consonants of Standard Arabic. She felt that her pronunciation was perceived as arrogant, and reported that:

The members of the recruiting committee advised me not to use my accent because they thought that my pronunciation of many sounds made them ambiguous. They told me to stop sounding stylish since students from other parts of the country would feel inferior to this Ammani accent, which was unacceptable. However, I think my pronunciation is normal and not superior to anybody. Besides, so many people would love to mimic my accent. I speak in a very elegant manner and people are usually pleased with my accent all over Amman. I felt that they were only biased against me because of my origin. This bias is felt when I apply for jobs outside Amman. It seems that I should only work in Amman.

The Urban accent is usually preferred by females because it represents modernity, femininity, style and elegance and is prestigious. Men are usually not comfortable with this way of speaking because they feel that this pronunciation is only suitable for females. Most of the members of the recruitment committee were males. In addition, males usually describe this pronunciation as "too fashionable" and hence not suitable for university classes, since half of the students are males. This linguistic inequality based on gender differences is a critical issue in the workplace especially when there are no powerful females there. In educational institutions "powerful" should mean both higher academic ranks and good representation of females on recruitment committees.

The other serious issue is the fact that some people may be discriminated against because of their origins. Accent may translate into region or sect. If one attacks a 
certain pronunciation, then the attacked people may feel that the negative comments are against their origin, i.e. their identity rather than against their accent.

\subsection{Remarks provided by Arabic instructors who took no issue}

\section{Instructor $D$}

Instructor D has a PhD in Arabic Literature. He has a Bedouin accent, as spoken in the southern part of Jordan. After his interview with the recruitment committee at the Language Centre, he reported:

\footnotetext{
The interviewers told me that I pronounced most of words with a very close pronunciation of regional Arabic. They argued that I have to stick to Standard Arabic when I teach in the future. Although I am proud of my southern accent, I felt that they were right. I think Standard Arabic is more appropriate for teaching. I did not feel discriminated against at all. I think I will be more aware of my southern pronunciation and stop using it. My accent is less likely to be understood by some students, especially as I speak quickly, which may pose a barrier to students. I believe that language in a teaching environment should pose no problem to any student.
}

He took no issue with the directives, believing that Standard Arabic is more suitable for instruction. He did not feel that his identity was being threatened by comments against his southern accent, since he is convinced that a standard form of pronunciation is more helpful to students.

\section{Instructor $E$}

Instructor E recently completed his MA in Arabic syntax. He had no previous involvement in teaching. He has the Rural accent spoken in the northern part of Jordan. After the interview he emailed us saying: 
The committee said that my rural accent is not suitable to use in the classroom. They added that I must correct my pronunciation according to Standard Arabic; otherwise it would be difficult to give me the chance to teach at the Language Centre. Since I think that they are more experienced in teaching, I think I should listen to them and avoid my Rural pronunciation; it has lots of emphatic consonants spreading even to adjacent vowels and therefore causing a problem. Employees should always listen to their mentors. I am so keen on this job and I have to listen to all the advice given by the committee in order to be a good teacher according to the norms of the institution where I want to work; otherwise I will face many difficulties in the future with my employer. I really thank them for their helpful directives.

Given the fact that Instructor E had no previous teaching experience, he agreed that the committee was more aware of what is good for instruction and what is not. He welcomed these directives in order to become a good part of the whole team and to work within the norms of the institution. He thinks that understanding the directives would help him being accepted by the group as part of the team.

\section{Instructor $\boldsymbol{F}$}

Instructor F recently finished her PhD in Arabic novels. She has taught in private secondary schools. She has the urban accent spoken in Amman. She told us:

My Urban pronunciation was not welcomed by the recruitment committee. The members told me that I must stop using my trendy pronunciation. They said that my accent is somehow "too fashionable". Actually, I believe that I should avoid my urban pronunciation in front of students because my consonants may result in problem of communication. I think that the regular standard pronunciation that does not show my regional identity is safer to use with students on campus. Moreover, I have to remember that the "educated" pronunciation is more relevant to our traditions and I am proud of our history of Arabic language which dates back thousands of years. I would love to see my 
students taught using a very educated style which may help them master the language of our early ancestors.

Although her fashionable and trendy pronunciation was not accepted by interviewers, she took no issue. Besides, she intends to avoid her regional pronunciation in future and to adopt an accent-free pronunciation which shows that the speaker is educated. This avoidance strategy is in keeping with the notion of the pure language of the earliest ancestors.

\section{Concluding remarks and implications}

The first three instructors perceived interviewers' directives negatively, whereas the second three took no issue. The first three perceived the directives as an example of linguistic bias, and they felt that such bias might reflect a negative attitude toward their accent, which is part of their identity. Moreover, the rejection of certain accents may endorse forms of language over other ones, resulting in imposing a dominant linguist form. Linguistic inequality results in a feeling of not belonging to the institution where people work. From the perspective of the second group of instructors, it seems that they have confidence in the interviewers, accepting their comments because they felt that they were valid, since such modifications are needed to avoid communication breakdown. They also acted in a manner relevant to historical appreciation of the language of the earliest ancestors. Finally, the question of job security was an important issue for some of the instructors.

Language identity is a pivotal part of societal practice. The diverse linguistic situations that individuals can participate in social life put demands on our definition of identity 'how individuals recognize their affiliation to the universe', and the constructing and restructuring of such an affiliation also within their vicinity, and the mindfulness of risks and gains of the future settings. Every time individuals speak, they are liable to influences of inferiority and superiority relations. Marginalized speakers of 
a certain language or dialect or accent in a certain state may be cherished in another. Consequently, speakers are involved in identity construction and negotiation: Cummins (2001), Canagarajah (2004), Heller (2007), Lin (2007) and Clarke (2008). Also Bonny Norton's conceptualization of identity (Norton, 2000, 2013) confirmed that individuals construct and negotiate unalike identities to restructure relationships so that they may assert their appropriate site.

Varghese et al. (2005) concluded that shaped identities were multiple and were in conflict. They also observed tensions between "claimed identity and assigned identity", They argue that the typical approaches do not contend with the concept of multiple group memberships. But if some do, they do not provide clear modelling about social settings that facilitates code switching as a strategy. Speakers are able to show a complex identity. Likewise, even speakers inside one crowd can differ in their degree of flexibility.

We hope that this study reveals the actual social pressures being placed on the interviewees themselves. According to Social Identity Theory (Tajfel \& Turner 1986), we have to understand instructors' identities as associated with both institutional contexts and group affiliations. Social Identity Theory also deals with a definite approach to hegemony, i.e. status relationships and mismatched identities, when dealing with teaching space. In a word, the question of identity is an individual and mental issue because it involves both self-image and other-image.

The research today investigates the link between identity language teaching by focusing on class, disability, sexual orientation, gender, and race. These issues are at the forefront of analysis within both applied linguistics. Matters of identity are not only pertinent to learners, but are also relevant to teachers and teacher's mentors. Moreover, openness to many theories enables us to understand the intricacy of identity issues. Approaches to identity are all valuable. Diverse viewpoints can assist us realize dissimilar sides of the intricacy of the question of identity. 


\section{References}

BARATTA, A. (2017) "Accent and linguistic prejudice within British teacher training", Journal of Language, Identity \& Education, 16:6, 416-423.

BARATTA, A. (2018) Accent and teacher identity in Britain: Linguistic favoritism an imposed identities, London: Bloomsbury.

BEINHOFF, B. (2016) "Perceiving identity through accent: Attitudes towards non-native speakers and their accents in English", Journal of Second Language Pronunciation, 2(1), 148-152. doi: 10.1075/jslp.2.1.07lin

BuzZELLI, C. A. \& B. JOHNSTON (2002) The moral dimensions of teaching: Language, power, and culture in classroom interaction, New York: Routledge Falmer.

CANAGARAJAH, S. (ed.) (2004) Reclaiming the local in language policy and practice, Mahwah, NJ: Lawrence Erlbaum.

CASAnAVe, C. P. \& S. R. SCHeCter (eds.) (1997) On becoming a language educator: Personal essays on professional development, Mahwah, NJ: Lawrence Erlbaum Associates, Inc.

CLARKE, M. (2008) Language teacher identities: Co-constructing discourse and community. Clevedon, UK: Multilingual Matters.

CUMmINS, J. $\left(2001^{2}\right)$ Negotiating identities: Education for empowerment in a diverse society, Los Angeles: California Association for Bilingual Education.

Deprez-SIMS, A. \& S. B. Morris (2010). "Accents in the workplace. Their effects during a job interview", International Journal of Psychology, 45, 417-426. doi: $10.1080 / 00207594.2010 .499950$

DUFF, P. A. \& Y. UHIDA (1997) “The negotiation of teachers' sociocultural identities and practices in postsecondary EFL classrooms", TESOL Quarterly, 31, 451-486.

Garrett, Peter (2010) Attitudes to Language, Cambridge: Cambridge University Press.

GILES, H. \& P. JOHNSON (1981) "The role of language in ethnic group formation", in J. Turner \& H. Giles (eds.), Intergroup behavior, Oxford: Basil Blackwell, 199-243.

GILES, H. \& P. JOHNSON, P. (1987) "Ethnolinguistic identity theory: A social psychological approach to language maintenance"; International Journal of the Sociology of Language, 68, 69-99.

Godley, A. \& A. ESCHER (2012) “Bidialectal African-American adolescents' beliefs about spoken language expectations in English classrooms", Journal of Adolescent and Adult Literacy, 55, 704-713. doi: 10.1002/JAAL.00085. 
GUMPERZ, J. J. (1970) Sociolinguistics and Communication in Small Groups, Working Paper 33, Berkeley: Language Behavior Research Laboratory, University of California.

Gutierrez, K. D. \& M. F. Orellana (2006) “The 'problem' of English learners: Constructing genres of difference", Research in the Teaching of English, 40, 502-507.

HADDIX, M. (2010) "No longer on the margins: Researching the hybrid literate Identities of black and Latina preservice teachers", Research in the Teaching of English, 45, 97-123. doi: $10.2307 / 40997086$

HADDIX, M. (2012) “Talkin' in the company of my sistas: The counterlanguages and deliberate silences of black female students in teacher education" Linguistics \& Education, 23, 160181. doi:_10.1016/j.linged.2012.01.003.

Hammarström, H., R. Forkel \& M. HASPELMATH (eds.) (2017) "South Levantine Arabic", Glottolog 3.0. Jena, Germany: Max Planck Institute for the Science of Human History.

HELLER, M. (1988) Codeswitching: Anthropological and sociolinguistic perspectives, New York: Mouton de Gruyter.

HELLER, M. (2007²) Linguistic minorities and modernity: A sociolinguistic ethnography, London, UK: Continuum.

INGHAM, B. (1982) North east Arabian dialects, London: Kegan Paul International.

KelCH, K. \& E. SANTANA-Williamson (2002) “ESL students' attitudes towards native and nonnative speaking instructors' accents" The CATESOL Journal, 14, 57-72.

Liberman, M. (2010) “Removing teachers with 'accented' speech?" <Retrieved from http://languagelog.Idc.upenn.edu/nll/?p=2365>.

LIN, A. (ed.) (2007) Problematizing identity: Everyday struggles in language, culture, and education, New York: Lawrence Erlbaum.

LIPPI-GREEN, R. (1997) English with an accent: Language, ideology, and discrimination in the United States, New York, NY: Routledge.

NORTON PEIRCE, B. (1995) “Social identity, investment, and language learning”, TESOL Quarterly, 29, 9-31.

NORTON, B. (2000) Identity and language learning: Gender, ethnicity and educational change. London: Longman.

NORTON, B. (2013) Identity and Language Learning: Extending the Conversation, Bristol: Multilingual Matters.

NUNAN, D. (1988) The learner-centered curriculum: A study in second language teaching. Cambridge, England: Cambridge University Press. 
Palva, H. (1991) "Is there a North West Arabian dialect group?", in M. Forstner (ed.), Festgabe für Hans-Rudolf Singer, zum 65. Geburtstag am 6. April 1990 überreicht von seinen Freunden und Kollegen, Part 1, Frankfurt: Peter Lang, 151-166.

Palva, H. (2006) "Dialects: Classification", in K. Versteegh et al. (eds.), Encyclopedia of Arabic Language and Linguistics, 1, Leiden: Brill, 604-613.

REASER, J. (2016) "Developing sociolinguistic curricula that help teachers meet standards", in K. Denham \& A. Lobeck (eds.), Linguistics at school, language awareness in primary and secondary education, Cambridge, UK: Cambridge University Press, 91-105.

SAKARNA, A. (2005) "The linguistic status of the modern Jordanian dialects", Arabica, 52, 522543.

SALKIND, N. $\left(2006^{6}\right)$ Exploring research, USA: Pearson, Prentice Hall.

SARUP, M. (1996) Identity, culture, and the postmodern world. Athens: University of Georgia Press.

TAJFEL, H. (1974) "Social identity and intergroup behavior", Social Science Information, 13, 6593.

TAJFEL, H. (1981) "Social stereotypes and social groups", in J. C. Turner \& H. Giles (eds.),

TAJFel, H., \& J. C. TURNER (1979) “An integrative theory of intergroup conflict”, in W. G. Austin \& S. Worchel (eds.), The social psychology of intergroup relations, Monterey, CA: BrookesCole, 33-47.

TAJFel, H. \& J. C. TURNER (1986) "The social identity theory of intergroup behaviour", in S. Worchel \& W. G. Austin (eds.), Psychology of Intergroup Relations, Chicago, IL: NelsonHall, 7-24.

VARGHESE M., M. MORGAN, B. JOHnStON \& K. JOHNSON (2005) "Theorizing language teacher identity: Three perspectives and beyond", Journal of Language, Identity, and Education, 4:1, 21-44.

WATSON, J.C.E. (2011) "Arabic dialects: General article", in S. Weninger et al. (eds.), The Semitic Languages: An International Handbook, 1. Berlin: Mouton de Gruyter, 851-896.

Woods, D. (1996) Teacher cognition in language teaching, Cambridge, Cambridge University Press. 